\title{
Antibacterial and antioxidant activity of methanolic extract of bark of Prunus persica
}

\author{
Rakesh R aturi*1, Harpreet Singh ${ }^{1}$, P. Bahuguna ${ }^{1}$, S. C. Sati ${ }^{2}$ and P. P. Badoni ${ }^{1}$ \\ ${ }^{1}$ Department of Chemistry, HNB Garhwal University Campus, Pauri Garhwal (U.K.), INDIA \\ ${ }^{2}$ Department of Chemistry, HNB Garhwal University, Srinagar Garhwal (U.K.), INDIA \\ *Corresponding author. E-mail: raakeshhh@gmail.com
}

\begin{abstract}
Abastract: In the present study in vitro antimicrobial and antioxidant activities of Prunus persica family rosaceae were carried out from the bark extract of the plant. The methanolic extract was tested for their antimicrobial study against gram positive and gram negative bacteria and for their antioxidant activity using scavenging activity of DPPH (1,1 diphenyl-2-picrylhydrozyl) radical method. The plant extract showed remarkable antibacterial and antioxidant activity.
\end{abstract}

Keywords: Antibacterial activity, Antioxidant activity, Prunus persica, Bacteria

\section{INTRODUCTION}

The plant extracts and active metabolites possess several types of activities such as antibacterial, antifungal, antioxidant and antiviral, etc. The various plant products, that are regularly used for their therapeutic potential (Mitscher, 1978 and Pavithra et al., 2010). The alternative medical therapy has increased the interest of pharmacologists and herbalists over the past decade. Historically, plants have provided a source of inspiration for novel drug compounds, as plant derived medicines have made contributions to human health and well being (El-Astal et al., 2005). Many studies indicates that in some plants there are many substances such as peptides, unsaturated long chain aldehydes, alkaloidal constituents, some essential oils, phenols and water, ethanol, chloroform, methanol, and butanol soluble compounds (Alma et al., 2003). These plants emerged as compounds with potentially significant therapeutic application against human pathogens, including bacteria, fungi or viruses (Holetz et al., 2002 and Perez, 2003). Prunus persica (L.) Aaru belongs to the family Rosaceae is a deciduous tree up to $10 \mathrm{~m}$. high. Bark gray or ashy or serrate acuminate glabrous. Flowers pinkish white sessile or short, Pedicelled. Commonly cultivate for edible fruit from sub. Himalayan up to $2400 \mathrm{~m}$. (Gaur, 1999). The leaves are astringent, demulcent, diuretic, expectorant, febrifuge, laxative, parasiticide and mildly sedative. They are used internally in the treatment of gastritis, whooping cough, coughs and bronchitis (Yeung Him-Che, 1985).

The plant has been used in folk medicines in India. There is a lack of information about the antibacterial and antioxidant activities of steam bark of P. persica, which is medicinal plant of the Indian flora and widely used in ISSN : 0974-9411 (Print), 2231-5209 (Online) All Rights Reserved ๑ Applied and Natural Science Foundation www.ansfoundation.org treating certain disease. This study is an attempt to determine the antibacterial and antioxidant activities of methanolic extract of $P$. persica steam bark.

\section{MATERIALS AND METHODS}

Test plant material: The Plant material was collected from Singoli, Paurikhal, Tehri Garhwal, Uttrakhand, India in the month of August 2007 and identified from Taxonomy Laboratory, Department of Botany, H.N.B. Garhwal University Srinagar. A voucher specimen (GUH-8388) of the plant has been kept in the Departmental Herbarium for future records.

Test organisms: The bacterial cultures used in this study, Staphylococcus aureus, Bacillus subtilis, Staphylococcus epidermidis, Klebsiella pneumoniae and Mycobacterium smegmatis were obtained from the SBS Institute of Biomedical Sciences Balawala, Dehradun, India.

Extract preparation and antimicrobial assay: The Bark $(3 \mathrm{~kg})$ was air dried, crushed, powdered and exhaustively extracted with light petroleum $\left(60-80^{\circ} \mathrm{C}\right)$. The petroleum extract was concentrated and dried. The petroleum free mass then extracted with $\mathrm{MeOH}$ repeatedly, until the extractive became colorless.

In vitro antibacterial activity of the methanolic extract of plant was carried out by disc diffusion method (Elgayyar et al., 2001). Actively growing a log phase culture were mixed in soft agar and plated. The extract $(1 \mathrm{~g} / \mathrm{ml})$ was loaded into different filter paper discs prepared from Whatman No.1 filter paper. The discs were placed on the agar medium containing the culture and incubated for $24 \mathrm{~h}$ at $37^{\circ} \mathrm{C}$. The diameter of zone of growth inhibition was measure. The effects were compared with that of the 
Table 1. Antibacterial activity of bark of P. per sica.

\begin{tabular}{|c|c|c|c|c|c|c|}
\hline \multirow[t]{2}{*}{ Plant extract } & \multirow[t]{2}{*}{ Concentration (\%) } & \multicolumn{5}{|c|}{ Zone inhibition $(\mathrm{mm})$} \\
\hline & & S.a & B.S & S.e. & K.p. & M.S. \\
\hline \multirow[t]{3}{*}{ Methanolic } & 50 & 22 & 15 & 15.5 & 23 & 16 \\
\hline & 100 & 23 & 17 & 17 & 24 & 17.5 \\
\hline & 150 & 23.50 & 19 & 18.5 & 24 & 18 \\
\hline Marginal Mean & & 22.83 & 17 & 17 & 24 & 17.83 \\
\hline Ampicillin $(5 \mu \mathrm{g} / \mathrm{ml})$ & & 35 & - & 17 & 17 & 24 \\
\hline
\end{tabular}

S. a.- Staphylococcus aureus, B. s.- Bacillus subtilis, S.e.- Staphylococcus epidermidis, K. p- Klebsiella pneumoniae, M.s.M ycobacterium smegmatis

standard antibiotic Ampicillin $(5 \mu \mathrm{g} / \mathrm{ml})$.

Deter mination of antioxidant activity: In order to measure antioxidant activity DPPH free radical scavenging assay was used. This assay measures the free radical scavenging capacity of the extract under investigation. DPPH is a molecule containing a stable free radical. In the presence of an antioxidant, which can donate an electron to DPPH, the purple colour which is typical for free radical decays and the absorbance was measured at $517 \mathrm{~nm}$ using a double beam UV-VIS spectrophotometer (Brand et al., 1995). The methanolic extract were redissolved in methanol and various concentration (10, 20,50 and $100 \mu \mathrm{g} / \mathrm{ml}$ ) of extract was used. The assay mixture contained in total volume of $1 \mathrm{ml}, 500 \mu \mathrm{l}$ of extract, $125 \mu 1$ prepared DPPH and $375 \mu 1$ solvent (methanol). After $30 \mathrm{~min}$ of incubation at $25^{\circ} \mathrm{C}$, the decrease in absorbance was measured at $517 \mathrm{~nm}$ on spectrophotometer. The radical scavenging activity (RSA) was calculated as a percentage of DPPH using a discoloration using then equation.

$\% \operatorname{RSA}=\left[\left(\mathrm{A}_{0}-\mathrm{A}_{\mathrm{s}}\right) / \mathrm{A}_{0}\right] \times 100$

Where $\mathrm{A}_{0}$ and $\mathrm{A}_{\mathrm{s}}$ are the absorbance of control and test sample respectively

\section{RESULTS AND DISCUSSION}

The result of this study showed that methanolic extract of P. persica inhibited the growth of various species of gram positive and gram negative bacteria (Table 1). The extract showed significant effect on all gram positive and gram negative bacteria in lower concentration. The

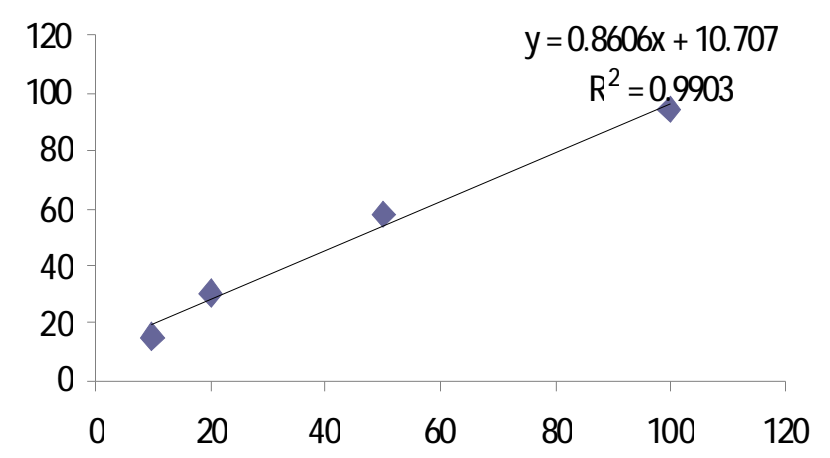

Fig. 1. DPPH activity of extract of P. per sica. inhibition zone of gram positive bacteria was found Staphylococcus aureus (22-23.5mm), Bacillus subtil is (15$19 \mathrm{~mm})$, Staphylococcus epidermidis (15.5-18.5mm) and gram negative bacteria Klebsiella pneumoniae (23-25mm), M ycobacterium smegmatis (16-18mm). The methanolic extract shows very good antibacterial activity due to the presence of several bioactive compounds such as $\beta$ sitosterol, its D-glucoside, hentriacontane, hentricontanol and flavonoids naringenin, di hydro-kaempferol, quercetin (Chandra et al., 1988), persicaside a new alkaloids (Jung-Rae et al., 2007) and also phenolic compounds have been isolated from the plant to exhibit antibacterial activity.

The DPPH radical has been widely used to test the potential of compounds as free radical scavengers of hydrogen donor and to investigate the antioxidant activity of plant extracts (Porto et al., 2000). The mehtanolic extract of plant showed a high effective free radical scavenging in DPPH (2,2 diphenyl-1-picryl hydrazyl) assay (Fig. 1). The extract of the plant exhibited a remarkable antioxidant effect at low concentration. When the extract of the plant was tested for DPPH radical scavenging activity, it was found that 50ìg/ml and 100ìg/ $\mathrm{ml}$ of the extract lowered the DPPH radical levels above $57 \%$ and $94 \%$ respectively. Inhabitation of DPPH radicals $50 \%$ considered as significant antioxidant properties of any compound (Sanchez-Moreno et al., 1998).

The results obtained in the present study showed that plant extract had good significant antibacterial activity against gram positive and gram negative bacteria and also remarkable antioxidant activity on DPPH free radical.

\section{ACKNOWLEDGEMENTS}

Authors are thankful to Dr. G. S. Bisht, SBS Institute Balawala Dehradun and Mr. Gurjinder Singh SKUAST Jammu for providing necessary facilities during the work.

\section{REFERENCES}

Alma M.H., A. Mavi, A. Yildirin, M. Digrak and T. Hirata (2003). Screening Chemical Composition and in vitro antioxidant and antimicrobial activities of essential oils from Origanum syriacum L. growing in Turkey. Biol. Pharma. Bull., 26: 1725-1729. 
Brand, W. W., Cuvelier H. E. and Berset C. (1995). Use of a free radical method to evaluate antioxidant activity. Food Sci. Technol., 82: 25-30.

Chandra, S. and Sastry, M. S. (1988). Phytochemical investigations on prunus persica heart wood. Indian journal of Pharamaceutical Sciences, 50:321-322.

Elagayyar, M., Draughon F.A., Golden D.A. and Mount J. R. (2001). Antimicrobial activity of essential oils from plants against selected pathogenic and saprophytic microorganism. J Food Prot., 64: 1019-1024.

El-Astal, Z. Y., Ashour, A.E.R.A. and Kerrit, A.A.M. (2005). Antimicrobial activity of some medicinal plant extract in Palestine. Pak. J. M ed. Sci., 21:187-193.

Gaur, R. D.(1999) Flora of the district Garhwal North West Himalayas, Transmedia, Srinagar Garhwal. pp.227.

Holetz F. B., G.L. Pessini, N. Sanches, D. A. Cortez, C. V. Nakamura and B. P. Filho (2002). Screening of some plants used in the Brazilian folk medicine for the treatment of infections diseases. M em. Inst. $\mathrm{O}$ swaldo C ruz, Rio de J aneiro, 97: 1027-1031.

Jung-Rae Rho, Chang-Soo Jun, Young-Ae Ha, Myung-Ja Yoo,
Ming-Xun Cui, Hwa Seung Baek, Jin-ALim, Young-Haeng Lee, and Kyu-Yun Chai (2007). Isolation and characterization of a new alkaloid from the seed of prunus persica L. and its anti-inflammatory activity. Bull. Korean Chem. Soc., 28:1289- 1293.

Mitscher L.A. (1978). Plant derived antibiotics. J . Chromatogr Libr., 15: 463-477.

Perez, R. M. (2003). Antiviral activity of compounds isolated from plants. Pharma. Biol., 41:107-157

Porto,C. D., Calligaris, S., Celloti, E. and Nicoli, M. C. (2000). Antiradical properties of commercial cognacs assessed by the DPPH Test. J . of Agric. F ood C hem., 48: 4241-4245.

Pvithra, Vani Karsha and O. Bhagya Lakshmi (2010). Antibacterial activity of black pepper (Piper nigrum Linn.) with special reference to its mode of action. Indian J ournal of N atur al Products and Resources, 1:213-215.

Sanchez-Moreno, C., Larrauri J.A. and Saura-Calixto F. (1998). Bishen Singh Mahendra Pal Singh Publication, New Delhi pp. 123-129.

Yeung Him-Che (1985) Handbook of Chinese Herbs and Formulas. Institute of Chinese Medicine, Los Angeles. 